\title{
Zakah Rate In Islamic Stock Performance Models: Evidence From Indonesia
}

\author{
Mohammad Farhan Qudratullah \\ UIN Sunan Kalijaga Yogyakarta \\ mohammad.qudratullah@uin-suka.ac.id
}

\begin{abstract}
There are three models commonly used to measure the performance of Islamic stocks, namely Treynor Ratio, Sharpe Ratio, and Jansen Index. One component of the three models is risk-free returns which is usually approached with interest rates, whereas interest rates are prohibited in the concept of Islamic finance. This paper will approach a risk-free return with zakat-rate on the Islamic capital market in Indonesia from January 2011 - July 2018, then compare it to a model that uses interest rates. The results obtained by the model with interest rates and zakahrate in this third model have very high suitability values, so that zakah-rate can be used as an alternative substitute for interest rates in measuring the Islamic stock performance. It does not contradict the concept of Islamic economics, besides, calculation of models with zakah-rate is simpler than models with interest rates.
\end{abstract}

Keywords: Islamic stock performance, Jansen index, Sharpe ratio, Treynor ratio, Zakah-Rate.

\section{INTRODUCTION}

Investment according to Islam is a muamalah activity that is highly recommended and Islam prohibits hoarding of property and threatens it with painful torture (QS. At-Taubah: 34), because by investing, personal assets owned could be productive and beneficial to himself and others, with the conditions of application guided by sharia principles.

'O people who believe, truly most of the Jews and Christian monks really need people's property by vanity and they obstruct (mankind) from the path of Allah. And those who keep gold and silver, and not spend them in the way of Allah, then tell them (they will get a painful punishment). (QS. At-Taubah: 34). 
The philosophical foundation of investing is also motivated by order to pay zakah for ownership of unproductive assets (Nadjib, 2008). According to Metwally (1995), a Muslim who invests his savings will not be affected by zakah but must pay zakah for the proceeds obtained.

Investment can be divided into two, namely real sector investment and financial sector investment. Along with the development of global trade and information technology, investment in the financial sector is growing rapidly, one of them is an investment in the capital market. In Indonesia, PT. Jakarta Stock Exchange (JKSE) has been publishing a list of Islamic mutual funds, stocks, and bonds in the Jakarta Islamic Index (JII) since July 3, 2000. The Islamic capital market experiences significant growth and shows the potential for development from year to year. From 2011 - 2018, it was noted that the capitalization of sharia shares in the Indonesia Stock Exchange increased by more than $86 \%$ from 1968 Trillion to 3667 Trillion, while the number of Islamic stock increased $77 \%$ from 234 to 414 (OJK, 2018).

Stock investments in the capital market, including in sharia stocks, are investments that have high risk but have a high level of profit (high riskhigh return) (Jogiyanto, 2007). If not done carefully, investing in the stock market can bring bankruptcy. To prevent such problems, risk management is needed. There are several ways to manage risk, namely accepting risk, avoiding risk, controlling risk, and transferring risk. Controlling risk is an effort to deal with risk and the recommended strategy is to form a portfolio.

One of the open problems in forming portfolios is how to choose the stocks that make up the portfolio of the many existing stocks?. In general, the selected shares are stocks that have the best performance. Since the late 60 's to the present, stock performance analyses models that have been used are Treynor Ratio (Treynor, 1965), Sharpe Ratio (Sharpe, 1966), and Jansen Alpha Index (Jansen, 1967). One component of the three gauges is a riskfree return that is usually approached by interest rates. While the concept of interest rates in Islam is classified as usury and usury is expressly prohibited in the Al-Quran (QS. Al-Imran (130).

'O people who believe, do not eat usury by multiplying and fearing God so that you may have good fortune' (QS. Al-Imran:130)

Research on the performance analyses of Islamic stocks in Indonesia using Sharpe Ratio, Treynor Ratio, and Jansen Index both using one or three of these tools has been widely conducted (Utami, et. al., 2011; Hasbullah, et. al., 
2013; Setiawan and Oktariza, 2013; Andhyka, 2017; Putri and Worokinasih, 2018). Some studies compared the performance of Islamic stocks and conventional shares (Hanafi and Hanafi, 2012; Hamzah and Yohanes, 2013; Lestari, 2015; Amalia and Kartikasari, 2016; Kusumawati, 2016; Huda, et al., 2017). Risk-free returns in these studies are still approached with interest rates, which is Bank Indonesia Certificates (BI-rate) in measuring their performance. Some researchers (Kurniawan and Asandimitra, 2014; Rumintang and Azhari, 2015; Djaddang and Susilawati, 2016; Tulasmi and Trihariyanto, 2016; Kholidah, et. al., 2019) approached risk-free returns using Bank Indonesia Syariah Certificates or Bank Indonesia SyariahWadiah Deposits. Other foreign researchers approached it with interest rates in their country such as the Kuala Lumpur Inter-Bank Offered Rate (KLIBOR) (Albaity and Ahmad, 2008; Mansor and Bhatti, 2011), Saudi Inter-Bank Offered Rate (SIBOR) (Merdad, et. al., 2010; Ashraf, 2013).

El-Askhar (1987) argues that the risk-free return is replaced by the zakah-rate which is equal to $2.5 \% /(1-2.5 \%)=2.56 \%$, the zakah-rate is the minimum rate of return expected for Muslim investors can fulfill his religious obligations. This opinion was conveyed to criticize the Capital Asset Pricing Model (CAPM) model. Based on this description, this paper will approach risk-free returns with zakah-rate on the Treynor Ratio, Sharpe Ratio, and Jansen Index that are implemented in the Indonesian sharia capital market, then compare them to models that use interest rates (BI-rate).

This study is different from previous studies that only use risk-free returns (BI-rate, Bank Indonesia Syariah Certificates, KLIBOR, SIBOR, or others) in measuring the performance of Islamic stocks without evaluating the predictive ability of these models. Thus, this research is very different from existing research.

This paper consists of several sections. Starting with an introduction that presents background, some related research, and the purpose of the research. Second, the literature review provides some theoretical bases used in this study, Third, the research method explains the data and the steps in analyzing the research problem. Fourth, the results of the study and discussion. In the last section, the conclusions and limitations of the study are presented.
Zakah Rate In

Islamic Stock

Performance

109 
IQTISHADIA

13,1

On July 3, 2000, the Indonesia Stock Exchange in cooperation with PT Danareksa Investment Management (DIM) launched a stock index based on Islamic sharia, the Jakarta Islamic Index (JII). This index is expected to be a benchmark for the performance of sharia-based stocks and to further develop the Islamic capital market. JII consists of 30 shares selected from stocks that are under Islamic sharia, whose shares are conducted by Bappepam-LK in collaboration with the DewanSyariahNasional (DSN) every 6 months through 2 stages, namely sharia selection and transaction volume value selection.

\begin{tabular}{|c|}
\hline Sharia Selection \\
\hline $\begin{array}{c}\text { Emitents do not run gambling/game businesses classified as gambling, and } \\
\text { trade that is prohibited }\end{array}$ \\
\hline $\begin{array}{c}\text { Not producing, distributing, and providing goods/services that are morally } \\
\text { damaging and harmful }\end{array}$ \\
Sharia Selection \\
\hline This process filters 6o shares with the highest market capitalist value on the \\
Indonesia Stock Exchange (IDX)
\end{tabular}

Source: Sudarsono, H. (2003)

Figure 1. Jakarta Islamic Index (JII) Stock Selection

\section{Zakah in Stock}

Zakah is one of five pillars in Islam, zakah plays a very important role in Moslem's life. Zakah is mentioned repeatedly, up to 32 times in the Quran indicating the importance of zakah in Islamic teaching (Andriani and Mairijani, 2019).

Zakah on shares is the zakah imposed on shares both on their nominal value or on profit after fulfilling the mandatory requirements of zakah such 
as achieving haul, nisab, and others (Al-Farisi and Setyawan, 2015). Several years ago there was a Fatwa of the Islamic Jurisprudence Committee, the Organization of the Islamic Conference, regarding the zakah of company assets stated: first, the shares of the company must be zoned by shareholders and the company can act as a representative of shareholders to distribute zakah. Secondly, the Managerial Board can channel the zakah of the company's shares like the subject of concrete law to pay zakah, in the sense that all shares contained in a particular company are considered like a person's property. Third, if the company does not pay the zakah of its shares, the shareholders must pay their respective zakah shares. Fourth, if an owner sells his shares in the midst of a haul, then the share price can be combined with his other assets, then pay his zakah all when the haul is perfect (Muzammil, 2003).

If the shareholder obtains a statement that his zakah has been paid by his company, it means that his zakah obligation has been completed. But if the shareholders do not obtain this information, zakah payments can be made based on the intention of the shareholders when investing. If the intention is to earn income, the zakah paid is zakat based on exploitation, which is $2.5 \%$ of the profit. If the intention is to buy and sell, the zakah paid is zakat based on trade, which is $2.5 \%$ of capital and profits (Fielnanda, 2017).

\section{Risk and Return}

The basic thing in investment decisions is the level of expected profits (return) and risk (Tandelilin, 2001). Return is the result (rate of return) obtained as a result of the investment made. There are several types of returns commonly used in calculations, namely simple net return $\left(r_{t}\right)$ and geometricreturnor log return $\left(R_{t}\right)$.

$$
\begin{aligned}
& r_{t}=\frac{P_{t}+D_{t}}{P_{t-1}}-1 \\
& R_{t}=\ln \left(\frac{P_{t}+D_{t}}{P_{t-1}}\right)
\end{aligned}
$$

Where, $r_{t}$ is the simple net return for period $t, R_{t}$ is the geometric return for period $t, P_{t}$ is the market price at the end period $t, P_{t-1}$ is the market price at the end period $t$, and $D_{t}$ is the dividends (or interest) received
Zakah Rate In

Islamic Stock

Performance

111 
IQTISHADIA

13,1

112

during period $t$. From equation (1) and (2) can be obtained relation log return and simple net return, i.e.: $R_{t}=\ln \left(r_{t}+1\right)$.

The expected return on investment is merely the weighted average of probably expected return (Sharpe, 1985). If there is $T$ observation, the expected return $\left(E\left(R_{t}\right)\right)$ can be expressed as:

$$
E\left(R_{t}\right)=\bar{R}_{t}=\frac{\sum_{t=1}^{T} R_{t}}{T}
$$

Risk is defined as the variability of returns on expected returns (Van Horne and Wachowics, Jr., 1992). To calculate risk, the most widely used method is the standard deviation of returns from their expected values. Standard deviation $\left(\sigma_{t}\right)$ can be expressed as:

$$
\sigma_{t}=\frac{\sum_{t=1}^{T}\left(R_{t}-\kappa_{t}\right)^{2}}{T}
$$

Besides standard deviation, risk can be measured using betastock. Beta stocks are a risk measure of the systematic risk of a stock relative to market risk (Jogiyanto, 2007).

$$
\beta_{t}=\frac{\operatorname{Cov}\left(R_{t} ; R_{m}\right)}{\operatorname{Var}\left(R_{m}\right)}
$$

Where, $\beta_{t}$ is the beta stock, $R_{m}$ is the market return, $\operatorname{Cov}\left(R_{t} ; R_{m}\right)$ is the covariance of stock return with market return, and $\operatorname{Var}\left(R_{m}\right)$ is the variance of the market return.

\section{Stock Performance Measures}

The development of the concept of stock or portfolio performance measures began in the late '6os pioneered by Jack L. Treynor (1965), William F. Sharpe (1966), and Michael C. Jansen (1967). This concept is based on the capital market theory and the three performance measures known as the composite (risk-adjusted) measure of portfolio performance (Samsul, 2006).

\section{Treynor's Model}

Treynor evaluates the performance of stocks or portfolios by using the past average return as an expected return and using beta as a risk benchmark. 


$$
T R=\left(\bar{R}_{t}-\bar{R}_{f}\right) / \beta_{t}
$$

Zakah Rate In

Islamic Stock

Performance

where $T R$ is the reward to the volatility of the Treynor model or

Treynor Ratio and $\bar{R}_{f}$ is the risk-free rate

\section{Sharpe's Model}

According to Sharpe, the performance of stocks or portfolios in the future can be predicted by using two measures, namely the expected rate of return and predicted variability of risk, which are expressed as standard deviations.

$$
S R=\left(\bar{R}_{t}-\bar{R}_{f}\right) / \sigma_{t}
$$

Where $S R$ is the reward to the volatility of the Sharpe model or Sharpe Ratio.

\section{Jensen's Model}

Whereas Jansen emphasized that the return result referred to the average return in the past while the minimum rate of return was expected return, where Jansen used the Capital Asset Pricing Model (CAPM) formula in the model.

$$
I J=\bar{R}_{t}-\left(\bar{R}_{f}+\beta_{t}\left(\bar{R}_{m}-\bar{R}_{f}\right)\right)
$$

where $I J$ is Jansen Index

\section{METHODS}

The data used in this study are monthly data from January 2011 - July 2018 which are divided into two groups, namely the first data for the period January 2011 - December 2015 and the second data period January 2016 July 2018. The data consist of closing price Islamic stocks that are consistently incorporated in the Jakarta Islamic Index (JII) for the period January 2011 - December 2015, Composite Stock Price Index in Indonesia (^JKSE), Bank Indonesia Certificates (BI-rate), and zakah-rate. 
IQTISHADIA

13,1

114

There are the following steps for analyzing the data:

1. Calculate the monthly return of selected shares and market returns (^JKSE) with equation (2) for each group of data.

2. Calculate stock and market expectation return values using equation (3), and stock risk which consists of standard deviations and beta stocks with equations (4) and (5).

3. Calculate the stock performance value using Treynor Ratio, Sharpe Ratio, and Jansen Index both with BI-rate $(B)$ and zakah-rate $(Z)$. To make it easier to distinguish between one model and another, notation of equations (6), (7), and (8) is modified as follows:

Treynor Ratio with BI-rate: $T R=\left(\bar{R}_{t}-\bar{B}\right) / \beta_{t}$

Treynor Ratio with zakah-rate: $T R-Z=\left(\bar{R}_{t}-\bar{Z}\right) / \beta_{t}$

Sharpe Ratio with BI-rate: $S R=\left(\bar{R}_{t}-\bar{B}\right) / \sigma_{t}$

Sharpe Ratio with zakah-rate: $S R-Z=\left(\bar{R}_{t}-\bar{Z}\right) / \sigma_{t}$

Jansen index with BI-rate: $I J=\bar{R}_{t}-\left(\bar{B}+\beta_{t}\left(\bar{R}_{m}-\bar{B}\right)\right)$

Jansen index withzakah-rate: $I J-Z=\bar{R}_{t}-\left(\bar{Z}+\beta_{t}\left(\bar{R}_{m}-\bar{Z}\right)\right)$

To distinguish the first data and the second data, the results of the calculation of the first data without an asterisk while the results of the second calculation data with an asterisk $\left(^{*}\right)$.

4. Determine the stock rank of each model both the first and the second data.

5. Create a scatterplot between rank shares with BI-rate and zakahrate for each model both the first data and the second data to see the suitability of the model with BI-rate and zakah-rate. And calculate the Spearman rank correlation value (Qudratullah, 2017):

$$
r_{s}=1-\frac{6 \sum_{i=1}^{n} d_{i}^{2}}{n\left(n^{2}-1\right)}
$$

where, $r_{s}$ is the Spearman rank correlation coefficient, $d_{i}=R_{A i}-R_{B i}$ , $R_{A_{i}}$ is the $i$ stock rank of the first model and $R_{B i}$ is the istock rank of the second model. 
The higher Spearman rank correlation value indicates the higher level of suitability between the model with BI-rate and zakah-rate.

6. Create scatterplot between the first data rank and the second data for each model both the BI-rate and zakah-rate to see its predictive ability. And calculate the Spearman rank correlation value using equation (9). The higher the Spearman rank correlation value indicates the higher the predictive ability

\section{RESULTS}

\section{Stock Return and Risk}

Based on table 1, for the first data, eight stocks have a positive return with the highest UNVR shares and three stocks have a negative mean return value with the lowest LSIP stock. While the stocks that have the lowest volatility are TLKM and stocks that have the highest volatility are LSIP. Judging from the beta value of shares, there are five stocks with beta stocks above 1 (meaning that these stocks have volatility values tend to be above market prices) with the highest being ASRI and there are six stocks that have a beta value below 1 (meaning the sensitivity of this share price is smaller than the market) with the lowest being UNVR.

For the second data, four stocks have a positive mean return with the highest UNTR shares, and seven stocks have a negative mean return value with the lowest LPKR shares. Stocks that have the lowest volatility are ASII and stocks that have the highest volatility are INTP. For the stock beta, eight stocks have a beta value above 1 with the highest being INTP and three stocks have a beta of stocks below 1 with the lowest being AALI.

This shows that there is no guarantee that the stock in the first data having the highest return will have the highest return in the second data. Likewise, stocks that have the lowest volatility in the first data will also have the lowest volatility in the second data, as well as the beta value of their shares. 


\begin{tabular}{cccccccc}
\hline \multirow{2}{*}{ No. } & \multirow{2}{*}{ Stock } & \multicolumn{3}{c}{ First Data } & \multicolumn{3}{c}{ Second Data } \\
\cline { 3 - 7 } & & Return & Std. Dev. & Beta & Return* & Std. Dev.* & Beta* $^{*}$ \\
\hline 1 & AALI & $-0,001402$ & 0,097083 & 0,47365 & $-0,008435$ & 0,084529 & 0,01302 \\
2 & ASII & 0,007077 & 0,071616 & 1,20024 & 0,003288 & 0,056214 & 1,46052 \\
3 & ASRI & 0,005687 & 0,133452 & 2,03534 & $-0,001521$ & 0,077147 & 1,21221 \\
4 & INTP & 0,008735 & 0,085185 & 1,00223 & $-0,008415$ & 0,106237 & 2,18201 \\
5 & KLBF & 0,015643 & 0,067057 & 0,92298 & $-0,003078$ & 0,063825 & 1,47644 \\
6 & LPKR & 0,011386 & 0,111678 & 1,32108 & $-0,034322$ & 0,089685 & 1,32248 \\
7 & LSIP & $-0,005512$ & 0,136616 & 0,75989 & $-0,002551$ & 0,100004 & 0,02695 \\
8 & SMGR & 0,007613 & 0,080079 & 1,38468 & $-0,008139$ & 0,073601 & 1,39115 \\
9 & TLKM & 0,016026 & 0,061762 & 0,56776 & 0,000237 & 0,065790 & 0,59147 \\
10 & UNTR & $-0,000284$ & 0,081653 & 0,89013 & 0,021894 & 0,080760 & 1,39992 \\
11 & UNVR & 0,016896 & 0,063775 & 0,12674 & 0,004663 & 0,057821 & 1,19492 \\
12 & IHSG & 0,005048 & 0,041172 & 1,000000 & 0,007138 & 0,027963 & 1,000000 \\
\hline
\end{tabular}

\section{Analyses of Sharia Stock Performance}

The Islamic stock performance analysis tools used were Treynor Ratio, Sharpe Ratio, and Jansen Index with BI-rate and zakah-rate as a substitute for riskfree returns for both the first and second data.

\section{Performance Analysis of Sharia Stocks using Treynor Ratio}

The results of sharia stock performance measurement using Treynor Ratio with BI-rate and zakah-rate, for the first data, both put UNVR, TLKM, KLBF, LPKR, INTP, ASRI, and UNTR at rank 1, 2, 3, 4, 5, 8 and 9, while the other ranks are slightly different, namely SMGR is ranked 6th and ASII is ranked 7th with BI-rate and Z-rate otherwise. For the second data, the BI-rate and Z-rate both place UNTR, UNVR, ASII, ASRI, SMGR, LPKR, LSIP, and AALI shares at rank $1,2,3,4,8,9,10$, and 11 , while for ratings 5 to 7 there is a slight difference, KLBF ranks 5, INTP, rank 6, and TLKM ranks 7 for models with BI-rate while for models with Z-rate puts KLBF ranked 6, INTP ranks 7, and TLKM ranks 5.

Tabel 2. Value and Ranking of Stock Performance with Treynor Ratio

\begin{tabular}{ccccccccc}
\hline \multirow{2}{*}{ Stock } & \multicolumn{3}{c}{ First Data } & \multicolumn{4}{c}{ Second Data } \\
\cline { 2 - 9 } & $\begin{array}{c}\text { Value } \\
\text { (TR) }\end{array}$ & $\begin{array}{c}\text { Rank } \\
\text { (TR) }\end{array}$ & $\begin{array}{c}\text { Value } \\
\text { (TR-Z) }\end{array}$ & $\begin{array}{c}\text { Rank } \\
\text { (TR-Z) }\end{array}$ & $\begin{array}{c}\text { Value } \\
\left.\text { (TR }^{*}\right)\end{array}$ & $\begin{array}{c}\text { Rank } \\
\left.\text { (TR }^{*}\right)\end{array}$ & $\begin{array}{c}\text { Value } \\
\text { (TR-Z*) }\end{array}$ & $\begin{array}{c}\text { Rank } \\
\text { (TR-Z*) }\end{array}$ \\
\hline AALI & $-0,01491$ & 11 & $-0,00747$ & 10 & $-1,06653$ & 11 & $-0,81163$ & 11 \\
ASII & 0,001181 & 7 & 0,004116 & 6 & $-0,00149$ & 3 & 0,000788 & 3 \\
ASRI & 0,000013 & 8 & 0,001744 & 8 & $-0,00576$ & 4 & $-0,00302$ & 4 \\
INTP & 0,003068 & 5 & 0,006584 & 5 & $-0,00636$ & 6 & $-0,00484$ & 7
\end{tabular}




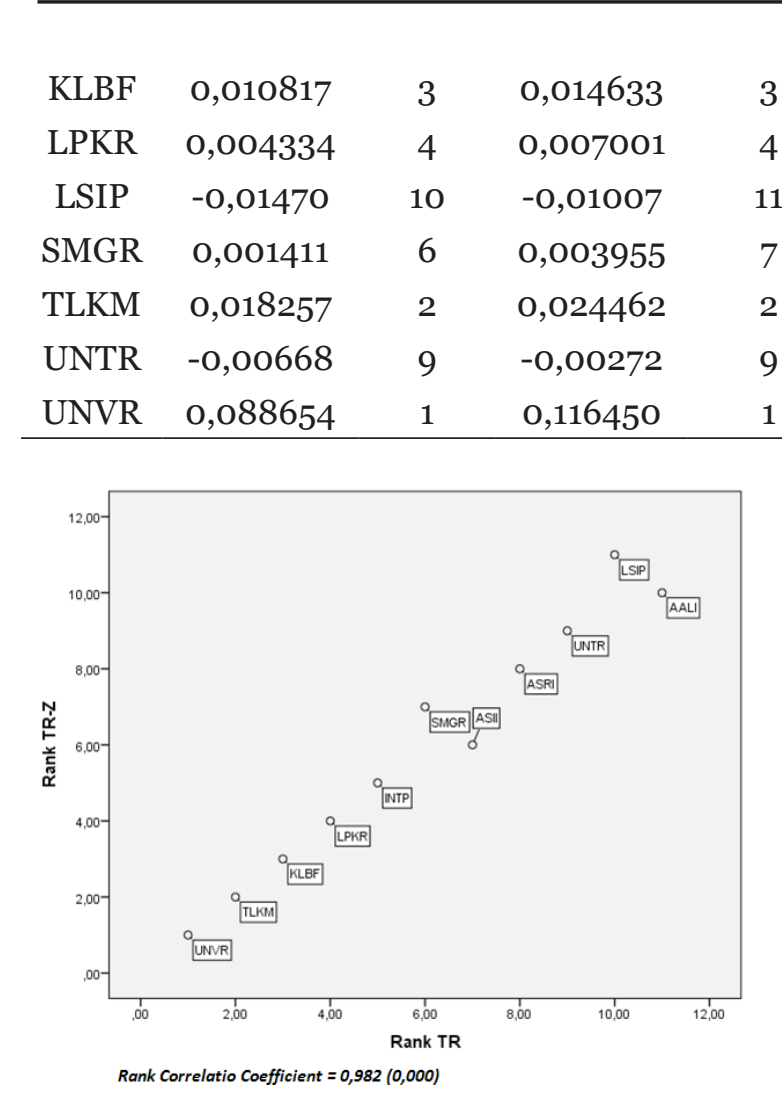

First Data

$\begin{array}{lcccr}-0,00578 & 5 & -0,00353 & 6 & \text { Zakah Rate In } \\ -0,03008 & 9 & -0,02757 & 9 & \text { Islamic Stock } \\ -0,29709 & 10 & -0,17391 & 10 & \text { Performance } \\ -0,00977 & 8 & -0,00739 & 8 & \\ -0,00883 & 7 & -0,00321 & 5 & 117 \\ 0,011741 & 1 & 0,014113 & 1 & \\ -0,00066 & 2 & 0,002114 & 2 & \end{array}$

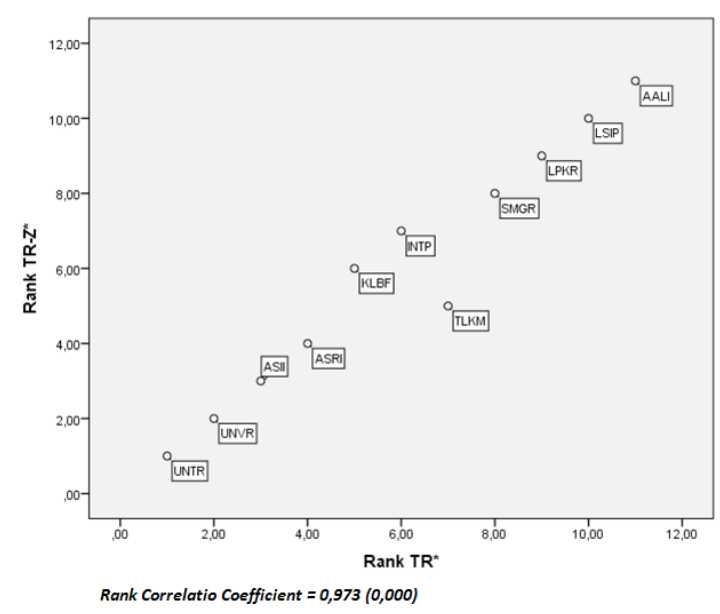

Second Data

Figure 2. Suitability Plot of Treynor Ratio with BI-Rate and Zakah-Rate

The suitability of sharia stock performance measurement using Treynor Ratio with BI-rate and zakah-rate can be seen from the rank correlation coefficient both for the first and second data, which is 0.982 for the first data and 0.973 for the second data in Figure 2. It appears that the two approaches provide results of performance measurement with very high suitability.
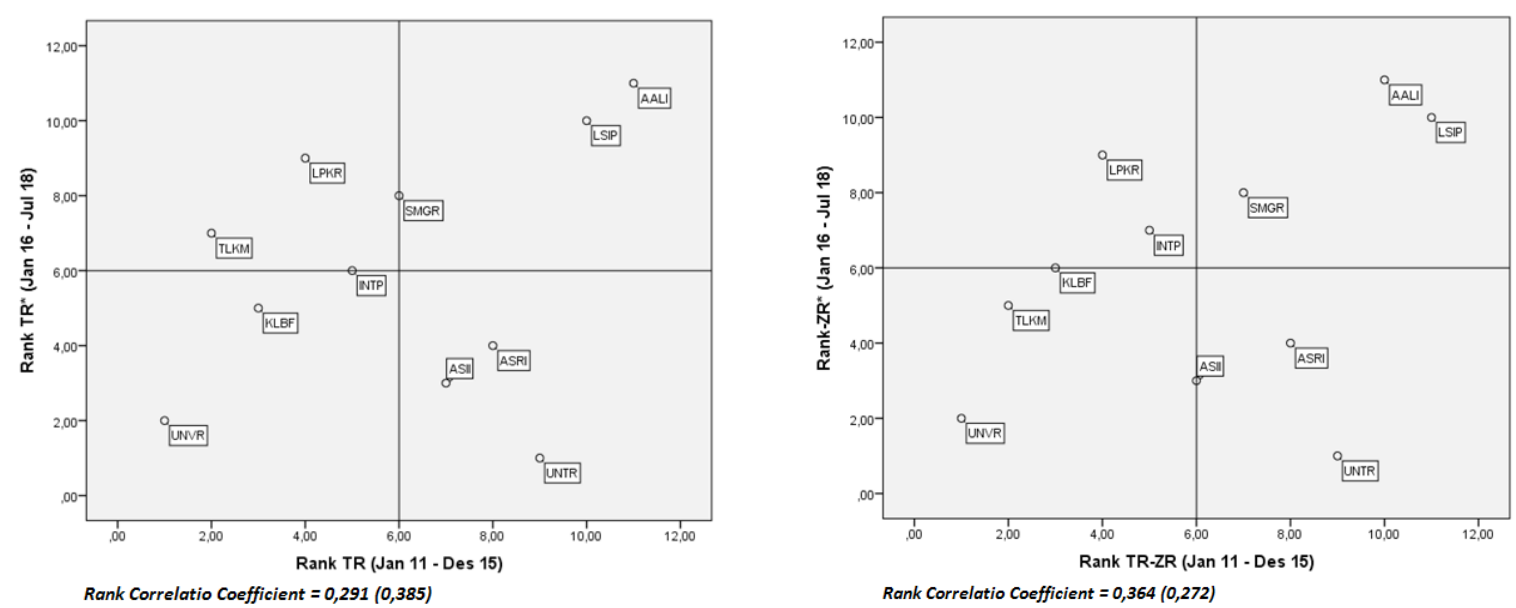

Figure 3. The Stock Performance Prediction plot uses the Treynor Ratio 
IQTISHADIA

13,1

118

The predictive ability of Islamic stock performance measurement using Treynor Ratio with BI-rate and zakah-rate can be seen from the correlation coefficient between the first and second data, which is 0.291 for Treynor Ratio with BI-rate and 0.364 for Treynor Ratio model with zakahrate (Figure 3). Although the predictive ability of the model with zakah-rate is slightly higher than the BI-rate model, the correlation is still weak and insignificant. This shows that the measurement results of the two models do not guarantee that stocks that have good performance in the first data will be the best in the second data.

\section{Performance Analyses of Sharia Stocks using Sharpe Ratio}

The results of Islamic stock performance measurement using Sharpe Ratio with BI-rate and zakah-rate, for the first data, both put UNVR, TLKM, KLBF, LPKR, INTP, ASRI, and LSIP at rank 1, 2, 3, 4, 5, 8 and 11, while the other ranks differ slightly, including AALI ranked 9th and UNTR ranked 1oth with BI-rate and Z-rate otherwise. For the second data, the BI-rate and Z-rate both place UNTR, UNVR, ASII, TLKM, LSIP, ASRI, AALI, and SMGR shares at rank 1, 2, 3, 4, 5, 6, 9, 10, and 11, while ratings 6 and 7 are slightly different, namely INTP rank 5 and KLBF rank 6 for models with BI-rate while those with Z-rate are the opposite.

Table 3. Value and Ranking of Stock Performance with Sharpe Ratio

\begin{tabular}{|c|c|c|c|c|c|c|c|c|}
\hline \multirow[b]{2}{*}{ CODE } & \multicolumn{4}{|c|}{ First Data } & \multicolumn{4}{|c|}{ Second Data } \\
\hline & $\begin{array}{c}\text { Value } \\
\text { (SR) }\end{array}$ & $\begin{array}{c}\text { Rank } \\
\text { (SR) }\end{array}$ & $\begin{array}{c}\text { Value } \\
\text { (SR-Z) }\end{array}$ & $\begin{array}{c}\text { Rank } \\
\text { (SR-Z) }\end{array}$ & $\begin{array}{l}\text { Value } \\
\left(\mathrm{SR}^{*}\right)\end{array}$ & $\begin{array}{l}\text { Rank } \\
\left(\mathrm{SR}^{*}\right)\end{array}$ & $\begin{array}{c}\text { Value } \\
\left(\mathrm{SR}-\mathrm{Z}^{*}\right)\end{array}$ & $\begin{array}{c}\text { Rank } \\
\left(\mathrm{SR}-Z^{*}\right)\end{array}$ \\
\hline AALI & $-0,07274$ & 9 & $-0,03645$ & 10 & $-0,16435$ & 9 & $-0,12507$ & 9 \\
\hline ASII & o,019791 & 7 & o,o6898 & 6 & $-0,03859$ & 3 & 0,020478 & 3 \\
\hline ASRI & 0,000205 & 8 & 0,02660 & 8 & $-0,09045$ & 6 & $-0,04741$ & 6 \\
\hline INTP & 0,036102 & 5 & 0,077458 & 5 & $-0,13058$ & 7 & $-0,09933$ & 8 \\
\hline $\mathrm{KLBF}$ & 0,148882 & 3 & 0,201419 & 3 & $-0,13373$ & 8 & $-0,08171$ & 7 \\
\hline LPKR & 0,051274 & 4 & 0,08282 & 4 & $-0,44354$ & 11 & $-0,40652$ & 11 \\
\hline LSIP & $-0,08177$ & 11 & $-0,05599$ & 11 & $-0,08008$ & 5 & $-0,04687$ & 5 \\
\hline SMGR & o,024394 & 6 & o,06839 & 7 & $-0,18473$ & 10 & $-0,13962$ & 10 \\
\hline TLKM & 0,167835 & 2 & 0,224876 & 2 & $-0,07934$ & 4 & $-0,02888$ & 4 \\
\hline UNTR & $-0,07280$ & 10 & $-0,02965$ & 9 & 0,203529 & 1 & 0,244641 & 1 \\
\hline UNVR & 0,176188 & 1 & 0,231429 & 1 & $-0,01373$ & 2 & 0,043696 & 2 \\
\hline
\end{tabular}

Like Treynor Ratio, the measurement results using the Sharpe Ratio also have very high suitability, which is 0.982 for the first data and 0.991 for the second data. Likewise, with predictive ability, the correlation coefficient 
between the first and second data is almost equal to zero, which is 0.082 for the Sharpe ratio model with BI-rate and -0.073 for the Sharpe Ratio model with zakah-rate.

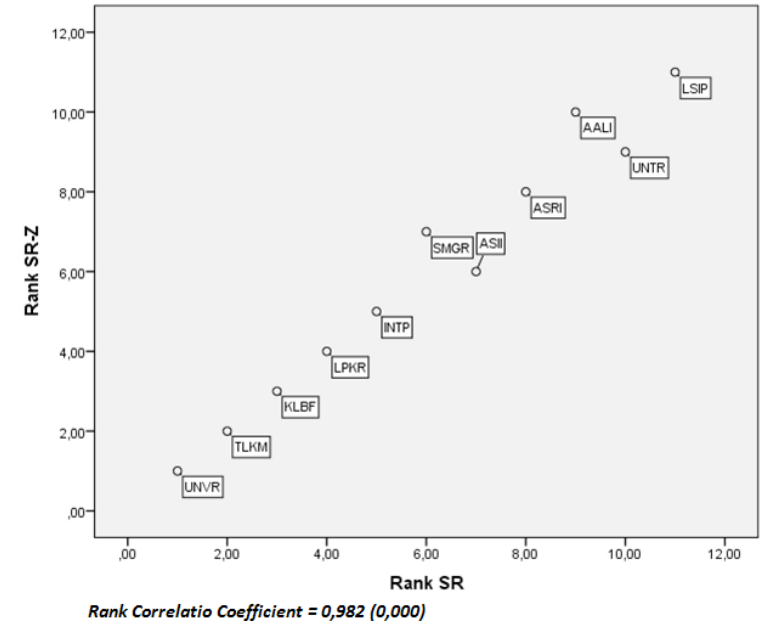

First Data

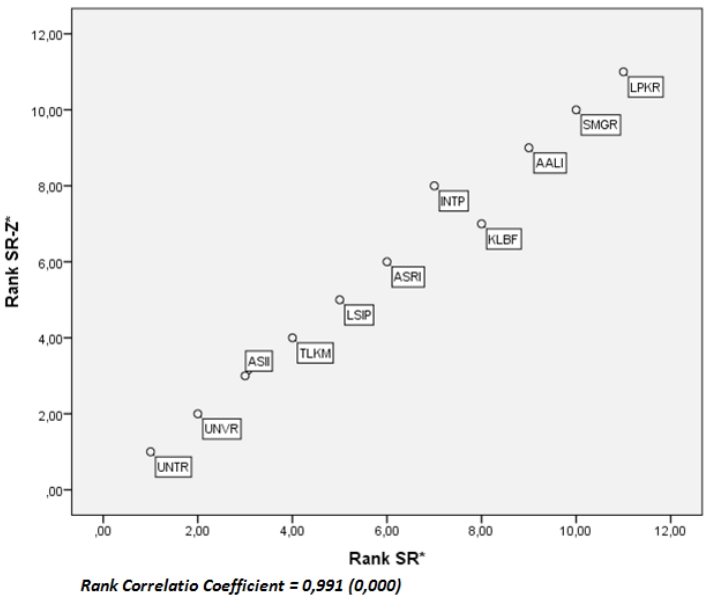

Second Data

Figure 4. Suitability Plot of Sharpe Ratio with BI-Rate and Zakah-Rate
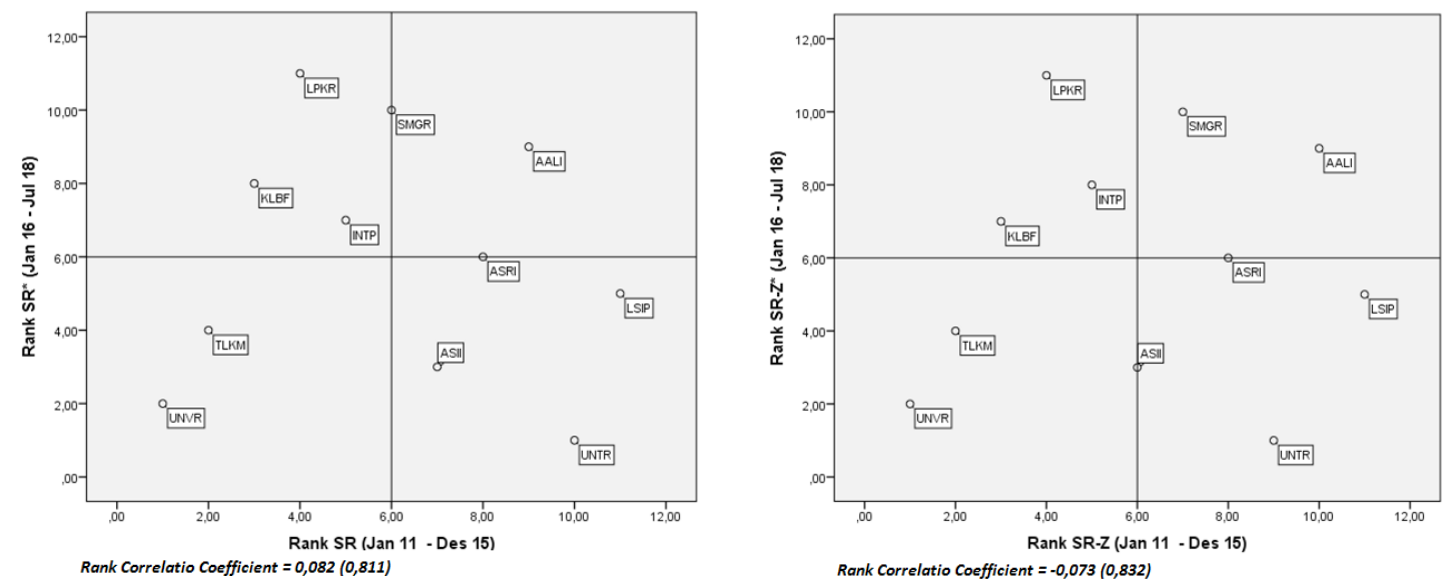

Figure 5. The Stock Performance Prediction Plot using the Sharpe Ratio

\section{Performance Analyses of Sharia Stocks using the Jansen Index}

The results of sharia stock performance measurement using the Jansen Index with BI-rate and zakah-rate, for the first data, both place UNVR, TLKM, KLBF, LPKR, INTP, ASRI, and LSIP at rank 1, 2, 3, 4, 5, 8 and 11, while the other ranks are slightly different, namely SMGR ranks 6 and ASII ranks 7, UNTR ranks 9 and AALI rank 10 with BI-rate and Z-rate otherwise. For the second data, the BI-rate and Z-rate both place UNTR, UNVR, TLKM, ASRI, SMGR, INTP, and LPKR at rank 1, 2, 4, 6, 9 and 10, while the other ranks are slightly different. 


\begin{tabular}{|c|c|c|c|c|c|c|c|c|}
\hline \multirow[b]{2}{*}{ CODE } & \multicolumn{4}{|c|}{ First Data } & \multicolumn{4}{|c|}{ Second Data } \\
\hline & $\begin{array}{c}\text { Value } \\
\text { (IJ) }\end{array}$ & $\begin{array}{c}\text { Rank } \\
\text { (IJ) }\end{array}$ & $\begin{array}{c}\text { Value } \\
(\mathrm{IJ}-\mathrm{Z})\end{array}$ & $\begin{array}{l}\text { Rank } \\
\text { (IJ-Z) }\end{array}$ & $\begin{array}{l}\text { Value } \\
\left(\text { IJ }^{*}\right)\end{array}$ & $\begin{array}{l}\text { Rank } \\
\left(\mathrm{IJ}^{*}\right)\end{array}$ & $\begin{array}{c}\text { Value } \\
\left(\mathrm{IJ}-Z^{*}\right)\end{array}$ & $\begin{array}{c}\text { Rank } \\
\left(\mathbf{I J}-Z^{*}\right)\end{array}$ \\
\hline AALI & $-0,00677$ & 10 & $-0,00492$ & 9 & $-0,01391$ & 8 & $-0,01064$ & 7 \\
\hline ASII & 0,00215 & 7 & 0,00145 & 6 & $-0,00462$ & 3 & $-0,00615$ & 5 \\
\hline ASRI & 0,00127 & 8 & $-0,00238$ & 8 & $-0,00902$ & 6 & $-0,00972$ & 6 \\
\hline INTP & 0,00369 & 5 & 0,00368 & 5 & $-0,01754$ & 10 & $-0,02146$ & 10 \\
\hline $\mathrm{KLBF}$ & 0,01055 & 3 & 0,01082 & 3 & $-0,01102$ & 7 & $-0,0126$ & 8 \\
\hline LPKR & 0,00653 & 4 & 0,00540 & 4 & $-0,042$ & 11 & $-0,04307$ & 11 \\
\hline LSIP & $-0,01071$ & 11 & $-0,00986$ & 11 & $-0,00805$ & 5 & $-0,00482$ & 3 \\
\hline SMGR & 0,00280 & 6 & 0,00145 & 7 & $-0,01593$ & 9 & $-0,01723$ & 9 \\
\hline TLKM & 0,01071 & 2 & 0,01224 & 2 & $-0,00621$ & 4 & $-0,00486$ & 4 \\
\hline UNTR & $-0,00540$ & 9 & $-0,00501$ & 10 & 0,014084 & 1 & 0,012756 & 1 \\
\hline UNVR & 0,01131 & 1 & 0,01439 & 1 & $-0,0028$ & 2 & $-0,00345$ & 2 \\
\hline
\end{tabular}

The suitability of Islamic stock performance measurements using the Jansen Index with BI-rate and zakah-rate is very high, which is 0.989 for the first data and 0.955 for the second data in Figure 6. While the predictive ability is very low, it can be seen from the rank correlation coefficient between the first and second data, which is -0.036 for the model with BI-rate and 0.210 for the model with the zakah-rate (Figure 7).

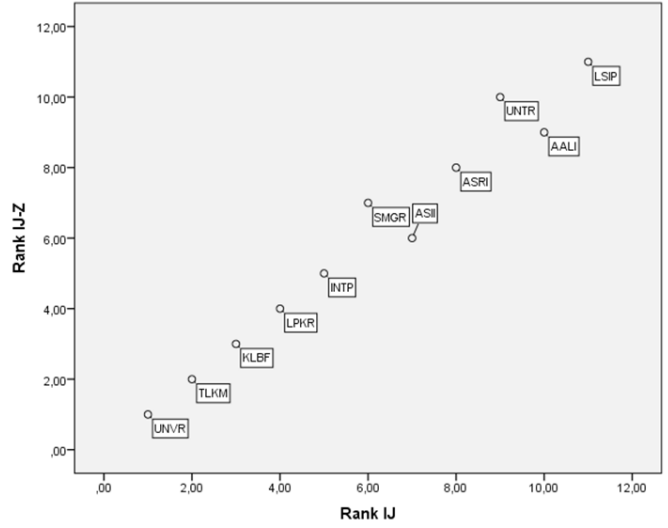

Rank Correlation Coefficient $=0,989(0,000)$

First Data

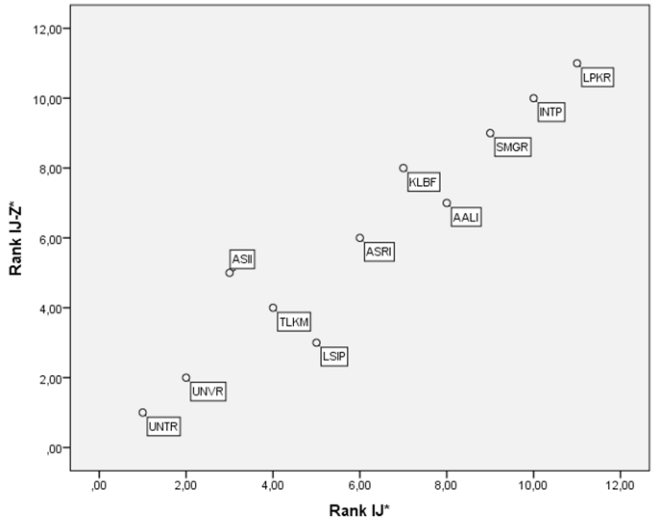

Rank Correlation Coefficient $=0,955(0,000)$

Second Data

Figure 6. Suitability Plot of Jansen Index with BI-Rate and Zakah-Rate 


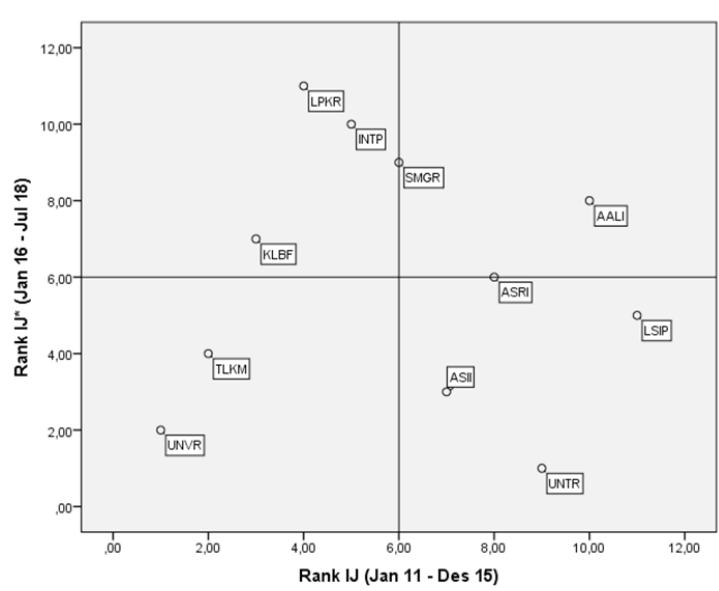

Rank Correlation Coefficient $=\mathbf{- 0} 0,036(0,915)$

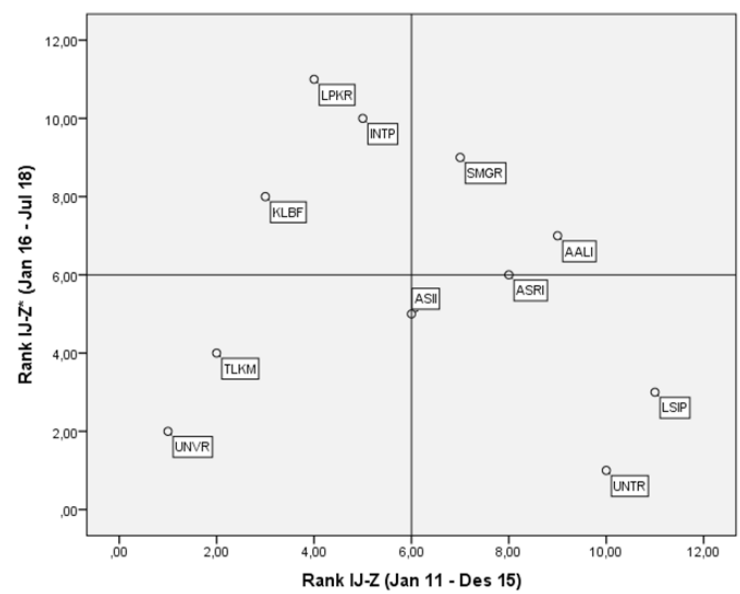

Rank Correlation Coefficient $=-0,210(0,536)$
Zakah Rate In

Islamic Stock

Performance

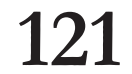

Figure 7. Stock Performance Prediction Plots using the Jansen Index

\section{DISCUSSION}

Analyses of the performance of sharia shares with the BI-rate and zakah-rate approach to measure risk-free returns yields a very high level of suitability, using Treynor Ratio, Sharpe Ratio, and Jansen Index of 0.982, 0.982 and 0.955 for the first data, and $0.973,0.991$ and 0.900 for the second data. This proves the opinion of El-Askhar (1987) that zakah-rate can replace risk-free returns in measuring the performance of Islamic stocks.

Seen from predictive ability, the zakat-rate tends to have a rank correlation value between the first and second data higher than the BI-rate both Treynor Ratio, Sharpe Ratio, and Jansen Index, all have very weak and weak and insignificant accuracy, which is $0.291,0.082,-0.036$ for the first data and $0.364,-0.073,-0.210$ for the second data. That is, there is no assurance that past performance is the best predictor of future performance. This is in line with Sharpe's opinion (1966).

\section{CONCLUSION}

Based on the description above, it is obtained that the results of performance measurement and predictive ability using the BI-rate with zakah-rate tend to be the same, both using the Treynor Ratio, Sharpe Ratio, and Jansen Index. Thus, it can be concluded that the risk-free return component contained in the three models in measuring the performance of sharia-based stocks can 
IQTISHADIA use the zakat-rate approach. The use of zakah-rate in measuring the 13,1 performance of Islamic stocks has several advantages, namely the model does not conflict with the concept of Islamic economics and a simpler model to be applied.

\section{LIMITATION}

This study only focuses on evaluating the use of zakah-rate in analyzing the performance of Islamic stocks in Indonesia. Evaluation of the use of zakah-rate in measuring risk-free returns can also be done using the Sharia Compliant Asset Pricing Model (SCAPM) both in predicting Islamic stock returns and in the formation of optimum portfolios.

\section{ACKNOWLEDGMENTS}

The authors gratefully acknowledges the grant from LP2M UIN Sunan Kalijaga Yogyakarta Indonesia

\section{References}

Albaity, M., and R. Ahmad. 2008. Performance of Syariah and Composite Indices: Evidence from Bursa Malaysia.Asian Academy of Managemen Journal of Accounting and Finance (AAMJAF) 4 (1): 23-43.

Al-Farisi, M. J., and E. Setyawan. 2015. Ijtihad Yusuf Qardhawi tentang Zakah Saham dan Obligasi. Al-Mustashfa: Jurnal Penelitian Hukum Ekonomi Islam 3 (2): 83-93.

Amalia, A. D., and D. Kartikasari. 2016. Analisis Perbandingan Kinerja saham Perusahaan Manufaktur Terindeks Syariah dan Konvensional. Jurnal Akuntansi, Ekonomi dan Manajemen Bisnis 4 (2): 128-135.

Andhyka, B. 2017. Sharia Equity Fund Performance Analysis (Indonesia's Case Study). IOSR-JBM: Journal of Business and Management 19 (11): 22-23.

Andriani and Mairijani. 2019. Strengthening Corporate Zakah Policy in Indonesia. Iqtishadia: Jurnal Kajian Ekonomi dan Bisnis Islam 12 (1): 70-88.

Ashraf, D. 2013. Performance Evaluation of Islamic Mutual Funds Relative to Conventional Funds: Empirical Evidence from Saudi Arabia. International Journal of Islamic and Middle Eastern Finance and Management 6 (2): 105-121. 
Djaddang, S., and Susilawati. 2016. Kinerja Saham Syariah dan Konvensional: Aplikasi Model Jensen. Jurnal Organisasi dan Manajemen 12 (2): 149-168.

El-Ashker, A. A. F. 1987. The Islamic Business Enterprise. London: Croom Helm

Fielnanda, R. 2017. Zakah Saham dalam Sistem Ekonomi Islam (Kajian atas Pemikitan Yusuf Qardhawi). Al-Tijary: Jurnal Ekonomi dan Bisnis Islam 3 (1): 57-67.

Hamzah, A., and A. Yohanes. 2014. Analisis Perbandingan Kinerja Reksa Dana Syariah dengan Reksadan Konvensional Jenis Saham pada Periode 2008-012. Jurnal MIX IV (3): 396-409.

Hanafi, M.M., and S.M. Hanafi. 2012. Perbandingan Kinerja Investasi Syariah dan Konvensional: Studi pada Jakarta Islamic Indeks (JII) dan Indeks LQ45. Ekbisi: Jurnal Ekonomi dan Bisnis Islam VII (1).

Hasbullah, E. S., I. B.Mohd, Mamat, SukonoM., and E. Rusyaman.2013. Analisis Perbandingan beberapa Saham Syariah dengan Menggunakan Model Volatilitas Tak Konstan. Statistika 13 (1): 25-31.

Huda, N. 2017. Analisis Perbandingan Kinerja Reksadana Saham Syariah dan Konvensional periode 2012-2015. IQTISHADIA: Jurnal Kajian Ekonomi dan Bisnis Islam 10 (2): 184-207.

Jansen, M.C. 1967. The Performance of Mutual Funds In The Period 19451964. Journal of Finance 23 (2).

Jogiyanto, H. 2007. Teori Portofolio dan Analisis Investasi, Edisi kelima. Yogyakarta: BPEE.

Kahf, M. 1999. The Principle of Socioeconomics Justice In The Contemporary Fiqh of Zakah. Iqtishad: JurnalOf Islamic EconomicsI.

Kholidah, N., M. R. Hakim, and E. Purwanto. 2019. Analisis Kinerja Reksadana Saham Syariah Dengan Metode Sharpe, Treynor, Jansen, $\mathbf{M}^{2}$, dan TT. Indonesian Interdisciplinary Journal of Sharia Economics 1 (2): 2940 .

Kurniawan, R. D. and N. Asandimitra. 2014. Analisis Perbandingan Kinerja Saham Syariah dan Kinerja Saham Konvensional. Jurnal Manajemen $2(4)$.

Kusumawati, R. 2016. Analisis Reksadana Konvensional dan Reksadana Syariah dengan Menggunakan Metode Sharpe. Jurnal Info Artha, 4 (July): 151-170.

Lestari, W. R. (2015). Kinerja Reksadana Saham Syariah dan Reksadana Saham Konventional. Jurnal Magister Managemeno1 (1). 
IQTISHADIA

13,1

Mansor, F., and M. I. Bhatti.2011. The Islamic Mutual Fund Performance: New Evidence on Market Timing and Stock Selectivity. International Conference on Economics and Finance Research (ICEFR 2011).

Merdad, H., M. K. Hassan, and Y.Alhenawi.2010. Islamic Versus Conventional Mutual Funds Performance in Saudi Arabia: A Case Study. JKAU: Islamic Econ23 (2), 157-193.

Metwally, M. M. 1995. Teori dan Model Ekonomi Islam. diterjemahkan oleh M. Husein Sawit. Jakarta: PT. Bangkit Daya Insana.

Muzammil, A. 2003. Tunaikan Zakat. Jakarta: Ikatan Keluarga Muslim Conoco Phillips Indonesia.

Nadjib, M.2008. Landasan FilosofiInvestasidalamIslam.InvestasiSyariah: Implementasi Konsep pada Kenyataan Empirik. Yogyakarta: Kreasi Wacana 3-47.

Otoritas Jasa Keuangan Republik Indonesia. 2018. Statistik Pasar Modal Syariah Indonesia: Desember 2018. http://www.ojk.go.id/.

Putri, D. T. H., and S. Worokinasih. 2018. Analisis Kinerja Investasi Reksa Dana Syariah di Indonesia denganMetode Sharpe, Treynor, dan Jansen. Jurnal Administrasi Bisnis (JAB) 59 (1): 134-143.

Qudratullah, M.F. 2017. Statistik Nonparametik: Teori Contoh Kasus dan Aplikasi dengan SPSS. Yogyakarta: Penerbit Andi.

Rumintang, A. G., and M. Azhari. 2015. Comparative Analysis of Performance of Conventional Equity Fund and Syariah Equity Fund using Sharpe, Treynor, and Jansen Method in 2014. e-Proceeding of Management 2 (2).

Samsul, M. 2006. Pasar Modal dan Managemen Portofolio. Jakarta: Erlangga.

Setiawan, C., and H. Oktariza. 2013. Syariah and Conventional Stocks Performance of Public Companies Listed on the Indonesia Stock Exchange. Journal of Finance and Economics 3 (1): 51-64.

Sharpe, W.F. 1966. Mutual Fund Performance. The Journal of Business39: 119-138.

Sharpe, W. F. 1985. Investments. $3^{\text {rd }}$ edition. Englewood Cliffs, New Jersey: Prentice-Hall.

Sudarsono, H.2003. Bank dan Lembaga Keuangan Syariah Edisi 2. Yogyakarta: Penerbit Ekonisia Fakultas FE UII.

Tandelilin, E. 2001. Analisis Investasi dan Manajemen Portofolio. Edisi Pertama. Yogyakarta: BPFE. 
Treynor, J.L. 1965. How to Rate Management of Investment Funds. Harvard Business Review43: 63-75.

Tulasmi and R. R. Trihariyanto.2016. Islamic Stocks Indeks Performance: Comparative Studies Betwen Indonesia and Malaysia. Signifikan: Jurnal Ilmu Ekonomi 5 (1): 69-82.

Van Horne, J., and J. M. Wachowics, Jr. 1992. Fundamentals of Financial Management eighth edition. Prentice-Hall International Edition.

Utami, R. and M. P. K. Nugraha.2011. Analisis Kinerja Saham Syariah dan Pengaruhnya terhadap Respon Pasar pada Perusahaan yang Tercatat di Jakarta Islamic Indeks. Jurnal Reviw Akuntansi dan Keuangan 1 (2): 161-172.
Zakah Rate In Islamic Stock Performance 